\title{
Covid-19: Testing times for the government-but not for NHS staff
}

The UK government has not always stuck to its own advice on covid-19, says Andy Cowper. He argues that it must be clearer about its strategy and objectives

\author{
Andy Cowper editor \\ Health Policy Insight, London, UK
}

Covid-19 is no respecter of individual people, as shown by the rapid domino effect of infections in Whitehall—ranging from Chris Whitty, chief medical officer (now recovered and back at work), to the health secretary, Matt Hancock (who was visibly unwell at the opening of the NHS Nightingale Hospital at ExCeL London $^{1}$ ), to the prime minister's special adviser, Dominic Cummings, ${ }^{2}$ and the prime minister himself, Boris Johnson, who was admitted to intensive care on 6 April.

Of course, one wishes them all a speedy recovery. It does seem, however, that central government has been a bit sketchy in following its own official advice on social distancing, to put it mildly: the prime minister actually boasted that, on an early March hospital visit, he had still shaken hands with people. ${ }^{3}$ You also have to wonder about the cleaning standards at 10 Downing Street.

Scotland's chief medical officer, Catherine Calderwood, resigned after her family trips to a second home 40 miles away were made public. ${ }^{4}$ Calderwood does not seem to have broken any rules on social distancing, as only immediate family members joined her on these trips, but it's evidently untenable for a chief medical officer whose job is to advise the public to follow official guidance during this "lockdown" to fail to do so herself, to the letter.

\section{"Test, test, test"}

Hancock has set out a "five pillar" strategy for fighting covid-19, which will see the UK conducting as many as 100000 tests a day by the end of April. ${ }^{5}$ The five pillars of this strategy are NHS swab testing, swab testing for critical workers, antibody testing, surveillance testing for research, and a national diagnostic effort using commercial providers.

Johnson promised 25000 antigen tests a day for hospital patients last month. ${ }^{6}$ At the time of writing, NHS staff testing has yet to reach 7000 tests a day-although at least the bizarre policy of restricting staff testing to only $15 \%$ of available tests has been abandoned. ${ }^{7}$ Remarkably, NHS staff who turned up to the new drive-through testing centres were turned away if they didn't have an appointment email, at times when these centres were operating far below their capacity. ${ }^{8}$

There's clearly an issue with up to $30 \%$ of false negatives in the polymerase chain reaction test for the viral RNA of covid-19. ${ }^{9}$ Equally, there's an issue with the number of NHS staff off work and self-isolating because of virus symptoms or confirmed infection. How many are off work? Hancock told the BBC's Andrew Marr Show on Sunday that, judging by the latest data, $8 \%$ of NHS frontline staff were currently off work self-isolating, $5.7 \%$ of whom were doctors. ${ }^{10}$ (This number is contested as being too low by doctors' organisations. ${ }^{11}$ )

This challenging situation, in an already understaffed NHS, ${ }^{12}$ has been compounded by problems with the availability and distribution of personal protective equipment (PPE). Given the risk to clinicians' and colleagues' health and lives in their working proximity to the patients most seriously ill with covid-19, the depth and duration of these logistical issues have been unimpressive, and they won't have helped frontline staff's morale.

One unexpected consequence of this may be that, in the future, we'll see "onshoring" of production capacity for PPE supplies. On 2 April the government issued new and more stringent guidance for standards of PPE equipment to be worn. ${ }^{13}$

\section{Clarity of thought}

The government's communication over this pandemic has been poor. ${ }^{14}$ At the daily televised press briefings, government and medical spokespeople have kept saying that "our strategy is to save lives and save the NHS." There's one small problem: that's not a strategy. Saving lives and the NHS are objectives; reducing covid-19 transmission to a rate below 1:1 is their strategy, and encouraging the population to stay at home and maintain social distancing are their main tactics to deliver those objectives. Yes, 
this is a point of language, but language matters: it reveals clarity of thought.

The national media have started to notice the government's ineptitude. Even the pro-Johnson Telegraph (for which the prime minister is a longstanding columnist) has noticed this, as shown in a recent front page headline, "Questions without answers."15 When the Telegraph joins the rest of the national media in criticising a Conservative government's performance, much of what seems like the normal laws of politics has clearly been suspended.

It remains to be seen whether Keir Starmer, the newly elected Labour Party leader, can establish himself positively in the public perception during this crisis. ${ }^{16}$ Starmer has made the smart move of leaving Jonathan Ashworth in place as shadow health secretary. Ashworth's persistent, polite, undogmatic style has been highly effective, in its content and tone, at delivering constructive and measured opposition.

Finally, in Hancock's speech on 2 April he announced a "£13.4bn [€15.2bn; \$16.5bn] debt write-off” for the NHS. ${ }^{17}$ This didn't get as much media attention as it might have, given the more pressing concerns about testing and PPE, but the proper headline for this should have been, "Government writes off $£ 13.4$ bn of its historical underspending on the NHS."

\section{Competing interests: None declared.}

Provenance and peer review: Commissioned; not externally peer reviewed.

1 Hockaday J. Matt Hancock looks a little worse for wear as he opens NHS Nightingale Hospital. Metro 2020 Apr 3. https://metro.co.uk/2020/04/03/matt-hancock-looks-littleworse-wear-opens-nhs-nightingale-hospital-12503641/.

2 Dominic Cummings self-isolating with coronavirus symptoms. ITV News 2020 Mar 30. https://www.itv.com/news/2020-03-30/dominic-cummings-coronavirus/.

3 I shook hands with everybody," says Boris Johnson weeks before coronavirus diagnosis—video. Guardian 2020 Mar 27. https://www.theguardian.com/world/video/2020/ mar/27/i-shook-hands-with-everybody-says-boris-johnson-weeks-before-coronavirusdiagnosis-video.

4 Coronavirus: Scotland's chief medical officer resigns over lockdown trips. BBC News 2020 Apr 6. https://www.bbc.co.uk/news/uk-scotland-52177171.

5 Department of Health and Social Care. Health secretary sets out plan to carry out 100 000 coronavirus tests a day. $2 \mathrm{Apr} 2020$. https://www.gov.uk/government/news/healthsecretary-sets-out-plan-to-carry-out-100000-coronavirus-tests-a-day.

6 Department of Health and Social Care. Testing for coronavirus (COVID-19) will increase to 25000 a day. $18 \mathrm{Mar} 2020$. https://www.gov.uk/government/news/testing-forcoronavirus-covid-19-will-increase-to-25-000-a-day.

7 Ford M. Cap on covid-19 testing for frontline health staff lifted. Nursing Times $2020 \mathrm{Apr}$ 1. https://www.nursingtimes.net/news/coronavirus/cap-on-covid-19-testing-for-frontlinehealth-staff-lifted-01-04-2020/.

8 Bodkin $\mathrm{H}$, Levy M. Huge queues and "chaos" at drive-through coronavirus testing centre for NHS staff. Telegraph 2020 Apr 1. https://www.telegraph.co.uk/news/2020/04/01/hugequeues-chaos-drive-through-coronavirus-testing-centre-nhs/.

9 Butler C. Expert comment on different types of testing for COVID-19. Science Media Centre. 30 Mar 2020.https://www.sciencemediacentre.org/expert-comment-on-differenttypes-of-testing-for-covid-19/.

10 UK coronavirus live news: Hancock says no change to exercise rules as Calderwood steps down from daily briefings-as it happened. Guardian 2020 Apr 5. https://www. theguardian.com/world/live/2020/apr/05/uk-coronavirus-covid-19-live-news-hancockstarmer.

11 Royal College of Physicians. Covid-19 and its impact on NHS workforce. 5 Apr 2020. https://www.rcplondon.ac.uk/news/covid-19-and-its-impact-nhs-workforce.

12 NHS Digital. NHS vacancy statistics England February 2015-December 2019, experimental statistics. $27 \mathrm{Feb}$ 2020. https://digital.nhs.uk/data-and-information/publications/statistical/ nhs-vacancies-survey/february-2015---december-2019-experimental-statistics.

13 Public Health England, Department of Health and Social Care, NHS England. New personal protective equipment (PPE) guidance for NHS teams. 2 Apr 2020.https://www.gov.uk/ government/news/new-personal-protective-equipment-ppe-guidance-for-nhs-teams.

14 Cowper A. Andy Cowper: Covid-19-government communications need to build and sustain trust. BMJ Opinion 2020 Mar 20. https://blogs.bmj.com/bmj/2020/03/20/andycowper-covid-19-government-communications-need-to-build-and-sustain-trust/.

15 Daily Telegraph. The front page of tomorrow's Daily Telegraph: "Questions without answers". Twitter. 1 Apr 2020. https://twitter.com/Telegraph/status/1245453858366783489.

16 Labour Party. Leadership and deputy leadership election 2020-results. Apr 2020. https: //labour.org.uk/people/leadership-elections-hub-2020/leadership-elections-2020-results/

17 Department of Health and Social Care. NHS to benefit from $£ 13.4$ billion debt write-off. 2 Apr 2020. https://www.gov.uk/government/news/nhs-to-benefit-from-13-4-billion-debtwrite-off.

Published by the BMJ Publishing Group Limited. For permission to use (where not already granted under a licence) please go to http://group.bmj.com/group/rights-licensing/ permissions 